\title{
Perspektif Hukum Islam terhadap Pasar Modal Syariah Sebagai Alternatif Investasi Bagi Investor
}

\author{
Diana Wiyanti \\ Fakultas Hukum Universitas Islam Bandung \\ Jl. Taman Sari No. 1 Bandung 40116 \\ diana.wiyanti@yahoo.com
}

\begin{abstract}
The Islamic economic-social life including investment cannot be separated from Sharia principles. In capital market of Sharia, the activity to gaining wealth is always accompanied with the ways of remembering Allah SWT. This research is to analyze the concept of investment in accordance with Islamic laws; thus making it possible to observe the differences between investment and speculation based on Sharia. In addition, it is also to find out the perspective of Islamic laws towards the Sharia capital market. This research uses a descriptive-analytical method with judicial-normative approach in which the analysis is qualitatively done. The result of the research then shows that in the Sharia investment, the benefits for both the world and the hereafter are having the core priority in order to make the long-term investment. Meanwhile, speculation functions are merely to obtain a short-term profit without considering any other people's interest and mostly with the ways of breaking the accepted regulations. Islamic law highly supports the activities in Sharia capital market. This also is supported by the fundamental concept of Islamic law in Al Qur'an, Hadith, Figh and opinions of clergies.
\end{abstract}

Key words : Investment, sharia capital market, Islamic law

\begin{abstract}
Abstrak
Kehidupan sosial ekonomi Islam, termasuk investasi tidak dapat dilepaskan dari prinsip-prinsip syariah. Di pasar modal syariah, aktivitas mengejar harta kekayaan senantiasa dibarengi dengan mengingat Allah SWT. Penelitian ini mengkaji konsep investasi menurut hukum Islam, sehingga dapat diketahui perbedaan antara investasi dan spekulasi menurut syariah. Serta diketahui pula bagaimana perspektif hukum Islam terhadap pasar modal syariah. Metode yang digunakan adalah deskriptif analitis dengan pendekatan yuridis normatif, analisisnya bersifat kualitatif. Hasil penelitian menunjukkan bahwa dalam investasi syariah unsur kemaslahatan dunia dan akhirat mempunyai prioritas yang utama, sehingga investasi bertujuan jangka panjang. Sementara spekulasi bertujuan hanya untuk mencari untung dalam jangka pendek tanpa memperhatikan kepentingan orang lain serta sering kali menggunakan cara-cara yang melanggar aturan yang berlaku. Hukum Islam sangat mendorong aktivitas investasi di pasar modal syariah. Hal ini didukung oleh konsep dasar hukum Islam dalam AI Quran, hadis, fikih dan pendapat para ulama.
\end{abstract}

Kata Kunci : Investasi, pasar modal syariah, hukum Islam 


\section{Pendahuluan}

Investasi di Indonesia diawali sejak ratusan tahun yang lalu yaitu ketika hadirnya bangsa Portugis ke Selat Malaka pada 1511. Kedatangan bangsa tersebut adalah untuk berdagang rempah-rempah yang pada saat itu sedang laku keras di berbagai negara. Investasi asing di Indonesia terus berlanjut diantaranya dilakukan oleh Inggris dan China. ${ }^{1}$

Sejarah investasi di bidang pasar modal Indonesia dimulai sejak Pemerintahan Hindia Belanda mendirikan bursa efek di Batavia 14 Desember 1912 sebagai cabang Amsterdamse Effectenbureurs. Pasar modal saat itu berfungsi sebagai sumber pembiayaan perusahaan dan menggali pembiayaan bagi perkebunan milik Belanda yang tumbuh di Indonesia. ${ }^{2}$ Sampai akhirnya lahirlah Undang-Undang No. 8 Tahun 1995 tentang Pasar Modal sebagai landasan yuridis bagi kegiatan Pasar Modal Indonesia. Selain itu diatur pula oleh beberapa Peraturan Pemerintah antara lain, Peraturan Pemerintah No. 45 Tahun 1995 tentang Penyelenggaraan Kegiatan di Bidang Pasar Modal, Peraturan Pemerintah No. 46 Tahun 1995 tentang Tata Cara Pemeriksaan di Bidang Pasar Modal, Keputusan Menteri Keuangan, Peraturan Bapepam Lembaga Keuangan (LK), dan Peraturan Bursa.

Perangkat aturan yang lengkap ternyata tidak menjamin pasar modal Indonesia terbebas dari keterpurukan. Runtuhnya pasar modal Amerika Serikat di penghujung 2008 yang diakibatkan oleh krisis ekonomi global yang berimbas pada iklim investasi di Indonesia dan perekonomian nasional membuktikan betapa rapuhnya sistem hukum dan sistem ekonomi kapitalis yang dianut Indonesia. Kapitalisme mengakibatkan orang lebih berorientasi profit dan meniadakan nilainilai dalam transaksi ekonomi dan bisnis. Muaranya karena keserakahan dan kepentingan segelintir orang, sehingga selama orang berspekulasi maka akan terus ada krisis. ${ }^{3}$

Selain itu terdapatnya pelanggaran syariah dalam transaksi di pasar modal konvensional menjadi salah satu penyebab timbulnya krisis. Keterpurukan ekonomi dan konflik hukum berkepanjangan membutuhkan pranata hukum baru yang dapat digunakan sebagai alat untuk menyelesaikannya. Namun hukum yang

\footnotetext{
${ }^{1}$ Etty S. Suhardo, "Menuju Hukum Investasi yang Kondusif”, dalam Jurnal Law Review, Vol IX, No.2 Nopember 2009, Fakultas Hukum Universitas Pelita Harapan, hlm. 238.

${ }^{2}$ I Putu Gede Ary Suta, Menuju Pasar Modal Modern, SAD Satria Bhakti, Jakarta, 2000, hlm.1.

${ }^{3}$ Menabur Kapitalisme, Menuai Krisis, Sharing Majalab Ekonomi dan Bisnis Syariah, Edisi 23 Tahun III November 2008, hlm. 10 .
} 
bagaimanakah yang dapat digunakan sebagai alat untuk menyelesaikan permasalahan tersebut? ${ }^{4}$

Allah telah menjanjikan transaksi atau perniagaan yang menguntungkan di dunia dan akhirat bagi siapa saja yang mau bertransaksi di jalan Allah. Dengan demikian, manusia selain diciptakan hanya untuk menyembah Allah, dia juga dikaruniai kebebasan untuk memilih dua pilihan dengan konsekuensi masing-masing. Pertama, apabila ingin mendapat nikmat yang cukup dan berkah dari langit dan bumi serta keberuntungan (falah) di dunia dan akhirat maka ia harus hanya menghamba kepada Allah SWT. Dengan menjalankan Islam secara kaffah. Kedua, apabila ingin mendapat siksa dan tidak mendapat keberuntungan di dunia dan akhirat maka menghambalah kepada selain Allah atau amalkanlah Islam secara parsial. ${ }^{5}$

Syariah Islam mengatur hubungan antarsesama manusia dan lingkungannya dalam konsep muamalah yang dibagi menjadi dua: maddiyah (hubungan yang berkaitan dengan materi dan ekonomi) dan adabiyah (hubungan yang berkaitan dengan aspek moral dan sosial). Aktivitas investasi dan perdagangan di bursa efek termasuk muamalah maddiyah. Sudah saatnya setiap muslim yang terlibat dalam sektor ini menunjukkan bahwa Islam sebagai jalan hidup dapat diamalkan secara komprehensif, dan bahwa mereka dapat menjalankannya secara istiqomah. Mengingat siapapun yang bergelut dalam sektor ini dapat terjerumus dengan muamalah yang batil (maysir, bay'al-ma'dum, taghir, gharar, ikhtikar, bay' najasy, tadlis dan riba). ${ }^{6}$

Menjalankan hukum dan ekonomi dengan kecerdasan spiritual tidak dapat disangkal berkaitan erat dengan ajaran Islam. Islam merupakan agama yang komprehensif, yang memberikan tuntunan dalam seluruh aspek kehidupan manusia, termasuk tuntunan dalam transaksi dan kegiatan ekonomi yang menjadi bagian penting dari keseharian kehidupan manusia. Kajian ekonomi Islam, termasuk fatwa ulama, telah banyak yang melandasi argumentasi bahwa terdapat beberapa ketidaksesuaian mainstream economics yang berlaku saat ini dengan prinsip dan ketentuan syariah. ${ }^{7}$

Dalam Islam, kerangka kegiatan muamalah bidang ekonomi dibagi menjadi tiga turunan yaitu: konsumsi, simpanan dan investasi. ${ }^{8}$ Islam mendorong umatnya untuk melakukan investasi kekayaan atau hartanya. Meskipun demikian, dalam

${ }^{4}$ Abdul Manan, Aspek Hukum dalam Penyelenggaraan Investasi di Pasar Modal Syariah Indonesia, Kencana Prenada Media Grup, Jakarta, 2009, hlm. 3.

${ }^{5}$ Muhamad Nafik HR, Bursa Efeke dan Investasi Syariah, Serambi Ilmu Semesta, Jakarta, 2009, hlm 14.

${ }^{6}$ Ibid.

${ }^{7}$ M. Luthfi Hamidi, Jejak-jejak Ekonomi Syariah, Senayan Abadi Publishing, Jakarta, 2003, tanpa halaman.

${ }^{8}$ Muhamad, Dasar-dasar Kenangan Islam, Ekonosia, Fakultas Ekonomi UII, Yogyakarta, 2004, hlm 185. 
melakukan investasi harus memperhatikan kaidah-kaidah hukum yang telah diterapkan oleh syariah, yaitu larangan adanya bunga dalam Islam. ${ }^{9}$

Institusi pasar modal syariah merupakan salah satu "pengejawantahan" dari seruan Allah tentang investasi. Dalam Islam, investasi merupakan kegiatan muamalah yang sangat dianjurkan, karena dengan berinvestasi harta yang dimiliki menjadi produktif dan juga mendatangkan manfaat bagi orang lain. Al-Quran dengan tegas melarang aktivitas penimbunan (iktinaz) terhadap harta yang dimiliki. ${ }^{10}$ Islam memiliki sistem perekonomian yang diselenggarakan dalam rangka mewujudkan kesejahteraan kehidupan manusia baik secara material maupun non material.

\section{Rumusan Masalah}

Mengacu pada paparan di atas, pada tulisan ini akan dirumuskan permasalahan sebagai berikut. Pertama, bagaimanakah konsep investasi menurut hukum Islam? Kedua, apakah perbedaan antara investasi dan spekulasi menurut syariah? Ketiga, bagaimanakah perspektif hukum Islam terhadap pasar modal syariah?

\section{Tujuan Penelitian}

Adapun tujuan penulisan ini adalah untuk mengetahui, pertama, konsep investasi menurut hukum Islam. Kedua, perbedaan antara investasi dan spekulasi menurut syariah. Ketiga, perspektif hukum Islam terhadap pasar modal syariah.

\section{Metode Penelitian}

Penelitian ini bersifat deskriptif analisis karena dilakukan untuk mencari data secara teliti dan lengkap tentang karakteristik suatu keadaan atau gejala-gejala yang dapat membantu memperkuat teori mengenai pasar modal syariah. ${ }^{11}$ Penelitian ini menggunakan pendekatan yurisdis normatif, yaitu penelitian hukum yang sepenuhnya mempergunakan data sekunder ${ }^{12}$ dan analisisnya bersifat kualitatif.

\footnotetext{
${ }^{9}$ M. Luthfi Hamidi, Op. Cit., tanpa halaman.

${ }^{10}$ Q.S. at-Tawbah: 34.

${ }^{11}$ Soerjono Soekamto, Penelitian Hukum Normatif: Suatu Tinjauan Singkat, Jakarta, Raja Grafindo Persada,1995, $h \operatorname{lm} 10$

${ }^{12}$ Ibid, hlm. 13.
} 
Adapun pengumpulan data dilakukan dengan menggunakan teknik studi dokumen dan studi kepustakaan (library research). Teknik ini dilakukan untuk memperoleh data sekunder berupa: ${ }^{13}$ 1. bahan hukum primer: a) Al-Quran dan Hadis; b) Fatwa DSN-MUI; c) Peraturan perundang-undang yang relevan yaitu Undang-Undang No. 8 Tahun 1995 tentang Pasar Modal. 2. bahan hukum sekunder: a) hasil karya ilmiah para sarjana tentang ekonomi syariah; b) hasil-hasil penelitian tentang ekonomi syariah dan pasar modal syariah.

\section{Hasil Penelitian dan Pembahasan}

\section{Investasi Berdasarkan Syariah}

Kehidupan sosial ekonomi Islam, termasuk investasi, tidak dapat dilepaskan dari prinsip-prinsip syariah. Investasi syariah adalah investasi yang didasarkan pada prinsip-prinsip syariah, baik investasi pada sektor riil maupun sektor keuangan. Islam mengajarkan investasi yang menguntungkan semua pihak (win-win solution) dan melarang manusia mencari rejeki dengan berspekulasi. Islam juga melarang investasi yang mengandung unsur riba, gharar (mengubah kondisi certainty menjadi kondisi uncertainty untuk mendapat keuntungan), gambling, maysir (judi), menjual sesuatu yang tidak dimiliki, dan berbagai tr ansaksi lain yang merugikan salah satu pihak. ${ }^{14}$

Sehubungan dengan hal tersebut, Ibn Taimiyah mengemukakan beberapa ciri dan prinsip pasar sebagai implikasi dari doktrin kebebasan ekonomi dalam Islam sebagai berikut: 1) setiap orang bebas masuk dan meninggalkan pasar; 2) harus ada informasi yang jelas mengenai kekuatan pasar dan barang-barang dagangan (komoditi); 3) tidak boleh ada unsur-unsur monopoli; 4) haram hukumnya melakukan penyimpangan dari prinsip kebebasan ekonomi yang yang jujur, seperti melakukan sumpah palsu, takaran yang tidak tepat, dan niat buruk. Islam juga melarang produksi dan distribusi komoditi yang tercela, karena merusak kesehatan dan tatanan moral yang berlaku. ${ }^{15}$

Selain ciri-ciri dan prinsip di atas, terdapat pula beberapa prinsip mekanisme pasar yang berlaku dalam sistem ekonomi Islam yaitu: 1) kebebasan individu; 2)

\footnotetext{
${ }^{13}$ Ronny Hanitijo Soemitro, Metode Penelitian Hukum Yurimetri, Ghalia Indonesia, Jakarta, 1990, hlm. 24-25.

${ }^{14}$ Muhamad, Dasar-Dasar Keuangan..., Op. Cit, hlm. 23.

${ }^{15}$ Muhamad Nafik HR, Bursa Efeke dan..., Op. Cit, hlm. 56.
} 
hak dan kepemilikan atas harta; 3) perbedaan ekonomi dalam batas yang wajar; 4) jaminan sosial; 5) distribusi kekayaan; 6) larangan menumpuk dan menimbun harta; 7) efisiensi dan keseimbangan; 8) kesejahteraan individu dan masyarakat. ${ }^{16}$

Beberapa ahli mengemukakan pendapat yang berbeda tentang investasi. Kendati demikian, ada beberapa kesamaan dalam pengertiannya. Alexander dan Shape mengemukakan bahwa investasi adalah pengorbanan nilai tertentu yang berlaku saat ini untuk mendapatkan nilai di masa datang yang belum dapat dipastikan besarannya. Sementara itu, Yogiyanto mengemukakan bahwa investasi adalah penundaan konsumsi saat ini untuk digunakan dalam produksi yang efisien selama periode tertentu. Adapun Tandelilin, mendefinisikan investasi sebagai komitmen atas sejumlah dana atau sumber daya lain yang dilakukan pada saat ini dengan tujuan memperoleh keuntungan di masa datang. ${ }^{17}$

Berbagai definisi ini mengandung tiga unsur yang sama. Pertama, pengeluaran atau pengorbanan sesuatu (sumber daya) pada saat sekarang yang tidak pasti. Kedua, ketidakpastian mengenai hasil (resiko). Ketiga, ketidakpastian hasil atau pengembalian di masa datang. Pengeluaran atau pengorbanan dalam investasi diartikan sebagai pengorbanan sumber daya yang bersifat tangible assets misalnya dana dan properti, maupun intangible assets seperti tenaga dan pikiran. ${ }^{18}$

Dalam sistem ekonomi konvensional, seseorang melakukan investasi dengan motif yang berbeda-beda, diantaranya untuk memenuhi kebutuhan likuiditas, menabung agar mendapat pengembalian yang lebih besar, merencanakan pensiun, untuk berspekulasi, dan lain-lain. Sementara itu, Sumantoro menyebutkan tiga hal utama yang mendorong seseorang melakukan investasi, yaitu mendapatkan kehidupan yang lebih baik di masa mendatang, menghindari kemerosotan harta akibat inflasi, dan untuk memanfaatkan kemudahan ekonomi yang diberikan pemerintah. ${ }^{19}$

Dalam sistem ekonomi Islam, investasi syariah tidak saja membicarakan persoalan duniawi sebagaimana dikemukakan para ekonom sekuler. Terdapat unsur lain yang sangat menentukan berhasil tidaknya suatu investasi di masa depan, yaitu ketentuan dan kehendak Allah. Islam memadukan antara dimensi dunia dan akhirat. Setelah kehidupan dunia yang fana, ada kehidupan akhirat yang abadi.

\footnotetext{
${ }^{16}$ Ibid, hlm. 56-66.

${ }^{17}$ Ibid., hlm 67.

${ }^{18}$ Ibid.

${ }^{19}$ Ibid., hlm 68.
} 
Setiap muslim harus berupaya meraih kebahagiaan di dunia dan akhirat. Kehidupan dunia hanyalah sarana dan masa yang harus dilewati untuk mencapai kehidupan yang kekal di akhirat.

Islam mengajarkan bahwa semua perbuatan manusia yang bersifat vertikal (hubungan dengan Allah) maupun horisontal (hubungan manusia dengan manusia) merupakan investasi yang akan dinikmati di dunia dan akhirat. Karena perbuatan manusia dipandang sebagai investasi maka hasilnya akan ada yang beruntung ada pula yang merugi. Itulah yang disebut risiko yang harus dihadapi oleh investor. ${ }^{20}$

Investasi merupakan salah satu ajaran dari konsep Islam. Hal tersebut dapat dibuktikan bahwa konsep investasi selain sebagai pengetahuan juga bernuansa spiritual karena menggunakan norma syariah, sekaligus merupakan hakikat dari sebuah ilmu dan amal. Oleh karena itu, investasi sangat dianjurkan bagi setiap muslim. Hal tersebut dijelaskan dalam Al-Quran surat Al-Hasyr ayat 18 sebagai berikut: "Hai orang-orang yang beriman, bertaqwalah kepada Allah dan hendaklah setiap diri memperhatikan apa yang telah diperbuatnya untuk hari esok (akhirat), dan bertakwalah kepada Allah, sesungguhnya Allah Maha Mengetahui apa yang kamu kerjakan". ${ }^{21}$

Demikian Allah SWT memerintahkan kepada seluruh hambaNya yang beriman untuk melakukan investasi akhirat dengan melakukan amal shaleh sejak dini sebagai bekal untuk menghadapi hari perhitungan. Mengingat bahwa tiada seorangpun di alam semesta ini yang mengetahui apa yang akan diperbuat, diusahakan, serta kejadian apa yang akan terjadi pada hari esok. ${ }^{22}$ Terdapat lima kunci-kunci ghaib yang tiada seorangpun mengetahui kecuali Allah SWT semata, sebagaimana diriwayatkan oleh Imam Bukhari dan Muslim dari Ibnu Umar yaitu: 1. tidak ada yang mengetahui apa yang akan terjadi pada hari esok kecuali Allah. 2. tidak ada yang mengetahui kapan terjadi hari kiamat kecuali Allah. 3. tidak ada yang mengetahui apa yang terjadi atau yang ada dalam kandungan rahim kecuali Allah. 4. tidak ada yang mengetahui kapan turunnya hujan kecuali Allah. 5. tidak ada yang dapat mengetahui di bumi mana seseorang akan wafat. ${ }^{23}$

Oleh sebab itu, Islam memerintahkan umatnya untuk meraih kesuksesan dan berupaya meningkatkan hasil investasi. Di sisi lain, Islam memerintahkan umatnya

\footnotetext{
${ }^{20}$ Ibid., hlm. 68.

${ }^{21}$ Nurul Huda, Mustafa Edwin Nasution, Investasi pada pasar Modal Syariah, Kencana Prenada Media Grup, Jakarta, 2007, hlm. 17-18.

${ }^{22}$ Q.S. Lukman: 34.

${ }^{23}$ Ibid., hlm 19.
} 
untuk meninggalkan investasi yang tidak menguntungkan sebagaimana sabda Rasullulah saw: "Jadilah orang yang pertama, jangan menjadi yang kedua, apalagi yang ketiga. Barang siapa yang hari ini lebih baik dari hari kemarin maka ia termasuk golongan orang yang beruntung. Barang siapa yang hari ini sama dengan hari kemarin maka ia termasuk golongan yang merugi. Dan barang siapa yang hari ini lebih buruk dari hari kemarin maka ia termasuk golongan yang celaka." (HR. Thabrani). ${ }^{24}$

Allah berfirman dalam Q.S. Al-Taubah: 105: “Dan katakanlah: Bekerjalah kalian maka Allah dan Rasul-Nya serta orang-orang mukmin akan melihat pekerjaan kalian itu, dan kalian akan dikembalikan kepada (Allah) yang mengetahui akan yang gaib dan yang nyata, lalu diberikan-Nya kepada kalian apa yang telah kalian kerjakan." 25

Islam memandang semua perbuatan manusia dalam kehidupan sehari-harinya, termasuk aktivitas ekonominya sebagai investasi yang akan mendatangkan hasil (return). Return investasi dalam Islam sesuai dengan besarnya sumber daya yang dikorbankan. Hasil yang akan didapatkan manusia dari investasinya di dunia bisa berlipat-lipat. Sebagaimana firman Allah pada Q.S. Al'Imran: 145 yang berbunyi: "Barang siapa menghendaki pahala dunia, niscaya Kami berikan kepadanya pahala dunia itu, dan barang siapa menghendaki pahala akhirat, Kami berikan (pula) kepadanya pahala akhirat. Dan Kami akan memberi balasan kepada orang yang bersyukur."

Itulah nilai yang membedakan investasi Islam dari investasi konvensional. Jadi, investasi yang islami adalah pengorbanan sumber daya pada masa sekarang untuk mendapatkan hasil yang pasti, dengan harapan memperoleh hasil yang lebih besar di masa yang akan datang, baik langsung maupun tidak langsung seraya tetap berpijak pada prinsip-prinsip syariat secara menyeluruh ( $k a f f a h)$. Selain itu semua bentuk investasi dilakukan dalam rangka ibadah kepada Allah untuk mencapai kebahagiaan lahir batin di dunia dan akhirat baik bagi generasi sekarang maupun generasi yang akan datang. ${ }^{26}$

Dalam berinvestasi Allah SWT dan Rasul-Nya memberikan petunjuk (dalil) dan rambu-rambu pokok yang seyogianya diikuti oleh setiap muslim yang beriman, yaitu: 1. terbebas dari unsur riba (Riba adalah penambahan atas harta pokok tanpa adanya transaksi bisnis riil). 2. terhindar dari unsur gharar (sesuatu yang yang bersifat tidak

\footnotetext{
${ }^{24}$ Muhamad Nafik HR., Op Cit, hlm. 69.

${ }^{25}$ Ibid.

${ }^{26} \mathrm{Ibid}$, hlm. 70 .
} 
pasti/uncertainty). 3. terhindar dari unsur judi (maysir/setiap bentuk permainan yang mengandung unsur pertaruhan). 4. terhindar dari unsur haram (sesuatu yang disediakan hukuman bagi yang melakukan dan disediakan pahala bagi yang meninggalkan karena diniatkan untuk menjalankan syariatNya. 5. terhindar dari unsur syubhat (suatu perkara yang tercampur antara halal dan haram, tetapi tidak diketahui secara pasti apakah itu sesuatu yang yang halal atau haram, dan apakah ia hak atau bathil. ${ }^{27}$

Hadis Nabi Muhammad saw menyebutkan bahwa: "menetapkan harga terlalu tinggi terhadap orang yang tidak tahu harga adalah riba". Adapun definisi gharar dapat ditemukan melalui pengidentifikasian kandungan gharar. Sebagimana ditulis oleh Vogel dan Hayes," as with riba, figh scholars have been unable to define the exact scope of gharar." Demikian pula Badhawi mengatakan: "The price meaning of gharar is itself uncertain. The literatures does not give us an agrred definition and scholars rely more on enumerating individual instances of gharar as substitute for precise definition in term. Dalam bahasa Arab, gharar berarti risiko, kadang merujuk pula pada ketidakpastian (uncertainty). Ibn-Taimiyyah mengidentifikasikan gharar sebagai "things with unknowfate" sehingga "selling such things is maysir or gambling." 28

Sehubungan dengan paparan di atas, Pontjowinoto sebagaimana dikutip oleh Nurul Huda, mengemukakan bahwa terdapat beberapa prinsip dasar transaksi menurut syariah dalam investasi keuangan, yaitu: 1. transaksi dilakukan atas harta yang memberikan nilai manfaat dan menghindari setiap transaksi yang zalim. Setiap transaksi yang memberikan manfaat akan dilakukan bagi hasil; 2. uang digunakan sebagai alat pertukaran bukan komoditas perdagangan, fungsinya adalah sebagai alat pertukaran nilai yang menggambarkan daya beli suatu barang; 3. setiap transaksi harus transparan, tidak menimbulkan kerugian atau unsur penipuan di salah satu pihak baik secara sengaja maupun tidak sengaja; 4. risiko yang mungkin timbul harus dikelola sehingga tidak menimbulkan risiko yang besar atau melebihi kemampuan menanggung risiko; 5. dalam Islam setiap transaksi yang mengharapkan hasil harus bersedia menanggung risiko; 6. manajemen yang diterapkan adalah manajemen islami yang tidak mengandung unsur spekulatif dan menghormati hak asasi manusia serta menjaga lestarinya lingkungan hidup..$^{29}$

\footnotetext{
${ }^{27}$ Nurul Huda, Op Cit., hlm. 24-29.

${ }^{28}$ Muhamad, Op Cit., hlm. 106.

${ }^{29}$ Nurul Huda, Op Cit., hlm. 23.
} 


\section{Investasi dan Spekulasi Menurut Syariah}

Islam adalah agama yang sempurna dan mempunyai sistem tersendiri dalam menghadapi permasalahan kehidupan, baik yang bersifat material maupun nonmaterial. Karena itu ekonomi sebagai salah satu aspek kehidupan, tentu juga sudah diatur oleh Islam dalam Al-Quran dan As-Sunnah. ${ }^{30}$

Dalam mewujudkan kehidupan ekonomi, sesungguhnya Allah telah menyediakan sumber dayanya di alam raya ini. Allah SWT mempersilakan manusia untuk memanfaatkannya. ${ }^{31}$

Dalam istilah ilmu fikih, dinyatakan oleh kalangan Hanafiyah bahwa harta itu adalah sesuatu yang digandrungi oleh tabiat manusia. Namun harta itu tidak akan bernilai kecuali bila dibolehkan menggunakannya secara syariat. ${ }^{32}$ Salah satu kegiatan manusia yang berkenaan dengan harta adalah dengan berinvestasi di pasar modal. Islam sangat menganjurkan manusia berinvestasi agar harta tersebut lebih produktif dan bernilai.

Para pelaku investasi (investor) dalam dunia pasar modal secara garis besar terbagi menjadi 2 (dua) macam, yaitu tipikal yang berani mengambil risiko (risk taker) dan mereka yang tidak berani mengambil risiko (nonrisk taker). Risk taker terbagi lagi menjadi 3 (tiga) bagian, yaitu: 1. mereka yang berani mengambil risiko tinggi dengan harapan imbal hasil yang juga relatif tinggi (high risk high return); 2 . mereka yang cukup berani mengambil risiko yang moderat dengan imbal hasil yang juga moderat (medium risk medium return); 3. mereka yang hanya berani mengambil risiko dalam tingkat yang relatif rendah dengan imbal hasil yang juga relatif rendah (low risk low return).

Dan jika ditinjau dari faktor pelaku, maka investor dapat dibagi menjadi dua pelaku utama, yaitu pertama, investor perorangan (private). Kedua, investor yang bersifat institusional atau kelembagaan (corporate). Menurut Schweser sebagaimana dikutip Nurul Huda terdapat beberapa perbedaan arahan investasi antara investor individu dengan investor institusional sebagaimana tertuang dalam tabel berikut: ${ }^{33}$

\footnotetext{
${ }^{30}$ Ibid., hlm. 1.

${ }^{31}$ Q.S. al-Baqarah: 29 dan Q.S. al-Jatsiyah: 12-13.

${ }^{32}$ Ibid., hlm. 2-3.

${ }^{33}$ Ibid., hlm. 11-13.
} 
Tabel 1

Perbedaan Investor Individu dan Investor Institusional

\begin{tabular}{|c|c|}
\hline INVESTOR INDIVIDU & INVESTOR INSTITUSI \\
\hline $\begin{array}{l}\text { Subjektif dalam mendefinisikan risiko } \\
\text { (diukur dengan loosing money) }\end{array}$ & $\begin{array}{l}\text { Lebih objektif (diukur dengan standar } \\
\text { deviasi) }\end{array}$ \\
\hline $\begin{array}{l}\text { Karakteristiknya dipengaruhi oleh } \\
\text { faktor psikologis) }\end{array}$ & $\begin{array}{l}\text { Karakteristiknya dipengaruhi oleh siapa } \\
\text { penerima manfaat }\end{array}$ \\
\hline Dipengaruhi oleh stage in life & Dipengaruhi oleh asset liabilities \\
\hline $\begin{array}{l}\text { Dapat menempatkan dananya dimana } \\
\text { saja }\end{array}$ & Diatur oleh ketentuan pemerintah \\
\hline $\begin{array}{l}\text { Ketentuan perpajakan menjadi isu } \\
\text { yang sangat penting }\end{array}$ & $\begin{array}{l}\text { Ketentuan perpajakan bukan menjadi isu } \\
\text { yang penting }\end{array}$ \\
\hline
\end{tabular}

Baik investor individu maupun investor institusi dalam melakukan investasi tidak akan terlepas dari adanya risiko. Menurut syariah suatu perbuatan manusia dipandang sebagai suatu investasi maka hasilnya akan ada yang beruntung ada pula yang merugi, hal itu disebut dengan risiko. Setiap keputusan investasi selalu menyangkut dua hal yaitu risiko dan return. Risiko mempunyai hubungan positif dan linier dengan return yang diharapkan dari suatu investasi, sehingga semakin besar return yang diharapkan semakin besar pula risiko yang harus ditanggung investor. Semua bentuk investasi mengandung risiko atau ketidakpastian hasil. ${ }^{34}$ Islam tidak melarang umatnya untuk menanggung risiko dalam menjalankan investasi. Setiap mukmin harus melakukan tindakan yang terbaik untuk hari ini dan menyerahkan hasilnya kepada Allah. Sebab manusia tidak mengetahui hasil upaya yang dilakukannya saat ini. ${ }^{35}$

Husnan sebagaimana dikutip Muhamad Nafik, ${ }^{36}$ mengemukakan bahwa risiko adalah kemungkinan hasil yang menyimpang dari harapan. Besarnya keuntungan yang diharapkan dari setiap sekuritas tidaklah sama, bergantung pada besarnya risiko yang harus ditanggung oleh investor. Yang dapat dilakukan investor adalah meminimalkan risiko dengan memperhatikan besarnya pengaruh masingmasing faktor tersebut. Risiko dalam investasi timbul karena adanya ketidakpastian waktu dan besarnya return yang akan diterima investor. Syariat tidak menafikan fenomena tersebut. Penyimpangan hasil itu tidak termasuk dalam kategori maysir (judi) maupun gharar (penipuan), karena menurut Adiwarman sebagaimana dikutip

\footnotetext{
${ }^{34}$ Muhamad Nafik HR., Op Cit., hlm. 70.

35 Ibid., hlm. 23.

${ }^{36}$ Ibid., hlm. 70-71.
} 
Muhamad Nafik, gharar adalah transaksi yang yang mengandung ketidakpastian bagi kedua belah pihak yang melakukan transaksi sebagai akibat diterapkannya kondisi ketidakpastian suatu akad yang secara alamiah seharusnya mengandung kepastian. Sedangkan maysir adalah permainan peluang atau suatu permainan ketangkasan, ketika salah satu (atau beberapa) pihak harus menanggung beban pihak lain sebagai konsekuensi keuangan akibat permainan tersebut. ${ }^{37}$

Dalam berinvestasi di pasar modal terdapat beberapa istilah yang sering disamakan artinya padahal mempunyai makna yang berbeda. Istilah tersebut adalah gambling dan spekulasi. Terdapat perbedaan mendasar antara keduanya yang terletak pada penguasaan teknik dan pengetahuan seseorang berkaitan dengan suatu tindakan. Seseorang yang berjudi (gambling) cenderung melakukan tindakannya tanpa analisis, karena ia memang tidak punya teknik dan pengetahuan yang memadai. Sebaliknya spekulasi masih melibatkan analisis, bahkan kadang-kadang melibatkan informasi yang lengkap dan data yang akurat. Namun, kedua praktik itu sama-sama bertujuan untuk mencari untung dalam jangka pendek tanpa memperhatikan kepentingan orang lain. Selain itu spekulasi sering kali menggunakan cara-cara yang melanggar rule of the game yang berlaku.

Tentu saja persoalannya berbeda jika kita berbicara tentang investasi. Pendapat Radcliffe sebagaimana dikutip Muhamad Nafik ${ }^{38}$ mengatakan bahwa "speculator accept fairly risk, and speculator have a large portofolio turnover, where as investors have low turnover."

Meskipun pada praktik di lapangan agak sulit membedakan antara tindakan investasi dan tindakan spekulasi karena keduanya sama-sama bertujuan untuk mendapatkan pengembalian lebih terhadap apa yang mereka lakukan, utamanya sebagai pelaku di pasar modal, dapat diketahui perbedaan dari tindakan-tindakan keduanya. Perbandingan antara keduanya dapat dilihat pada tabel berikut ini:

Tabel 2

Tindakan Investasi dan Tindakan Spekulasi

\begin{tabular}{|l|l|}
\hline \multicolumn{1}{|c|}{ Investor } & \multicolumn{1}{|c|}{ Spekulator } \\
\hline $\begin{array}{l}\text { Rasional dalam mengambil keputusan } \\
\text { Berhati-hati dan melakukan analisis } \\
\text { dengan cermat }\end{array}$ & $\begin{array}{l}\text { Kadang-kadang tidak rasional } \\
\text { Melakukan analisis dengan cermat } \\
\text { walaupun kadang-kadang manipulatif }\end{array}$ \\
\hline
\end{tabular}

\footnotetext{
${ }^{37}$ Ibid., hlm. 71.

${ }^{38}$ Ibid., hlm 75.
} 


\begin{tabular}{|c|c|}
\hline Investor & Spekulator \\
\hline $\begin{array}{l}\text { Mengumpulkan informasi selengkap } \\
\text { mungkin }\end{array}$ & $\begin{array}{l}\text { Memanfaatkan informasi yang simpang } \\
\text { siur dan membuat rumor yang } \\
\text { menguntungkan dirinya }\end{array}$ \\
\hline $\begin{array}{l}\text { Mengharapkan pengembalian pada } \\
\text { jangka relatif panjang }\end{array}$ & $\begin{array}{l}\text { Mengharapkan pengembalian dalam } \\
\text { jangka yang relatif pendek (profit taking) }\end{array}$ \\
\hline $\begin{array}{l}\text { Pada umumnya risiko yang diambil } \\
\text { bersifat moderat }\end{array}$ & $\begin{array}{l}\text { Memanfaatkan kondisi risiko tinggi dalam } \\
\text { berspekulasi }\end{array}$ \\
\hline $\begin{array}{l}\text { Mengharapkan pengembalian yang } \\
\text { sesuai dengan risiko }\end{array}$ & $\begin{array}{l}\text { Mengharapkan pengembalian yang tinggi } \\
\text { dan menolak pengembalian yang rendah }\end{array}$ \\
\hline Menginginkan harga sekuritas sebagai & Tidak peduli dengan kondisi perekonomian \\
\hline cerminan informasi dan kondisi ekonomi & baik mikro maupun makro. Lebih menyukai \\
\hline $\begin{array}{l}\text { yang sebenarnya, baik mikro maupun } \\
\text { makro }\end{array}$ & $\begin{array}{l}\text { beraksi pada kondisi ekonomi yang } \\
\text { bergejolak }\end{array}$ \\
\hline $\begin{array}{l}\text { Berdampak pada pasar yang bergejolak } \\
\text { namun pasti (fluktuasi yang wajar) }\end{array}$ & $\begin{array}{l}\text { Berdampak pada pasar yang bergejolak } \\
\text { dengan fluktuasi yang tinggi }\end{array}$ \\
\hline
\end{tabular}

Perbedaan antar keduanya dapat dilihat dari bagaimana mereka mendapatkan, memanfaatkan, dan berperilaku terhadap informasi. Para spekulan berpendapat, orang yang paling menguasai informasi akan mendapatkan keuntungan yang paling tinggi. Mereka hanya mementingkan kepentingan sendiri dan tidak mempedulikan kepentingan dan kondisi ekonomi serta para pelaku pasar yang lain. Mereka mengharap keuntungan yang sangat besar meskipun orang lain dirugikan. Bagi mereka harta yang didapatkan adalah hasil jerih payah sendiri. Tindakan seperti itulah yang dilarang oleh Al-Quran.

Spekulasi dapat terjadi karena adanya kesenjangan informasi yang dimiliki para pelaku pasar modal. Hal ini dapat diantisipasi dengan menciptakan sistem perdagangan yang memenuhi tiga hal, yaitu fair information, full and all information, dan unmanipulated information. Informasi yang adil akan membuat pasar bergerak sesuai dengan kondisi ekonomi yang sebenarnya baik secara mikro maupun makro. Islam menghendaki pemerataan pendapatan, persaingan yang sehat, dan mengharamkan spekulasi dalam aktifitas ekonomi. Larangan terhadap spekulasi karena tindakan tersebut dianggap fasik sebagaimana ditegaskan dalam Surat Al Maidah ayat $3 .{ }^{39}$

\section{Perspektif Hukum Islam terhadap Pasar Modal Syariah}

Pasar modal sebagai tempat pertemuan antara penawaran dan permintaan surat berharga menyediakan sumber pembelanjaan jangka panjang yang akan

\footnotetext{
${ }^{39}$ Ibid., hlm. 75-77.
} 
diinvestasikan pada barang modal. Pasar modal dibedakan dalam dua segmen. Pertama, segmen non-sekuritas yang menyediakan dana dari lembaga keuangan langsung kepada perusahaan. Kedua, segmen sekuritas yang didefinisikan oleh Wong Ye sebagaimana dikutip Muhamad Nafik sebagai berikut: ${ }^{0}$ “...market place where people come together to buy and shell share. The price of share is there for determine by selling and buying pressure when the buying is stronger, we have a bull market and price appreciate. The reverse is true when seller appear to drive price down in a bear phase."

Tujuan segmen ini adalah memobilisasi dana jangka panjang untuk ditempatkan pada investasi jangka panjang di perusahaan-perusahaan produktif. Dalam segmen ini, investor dapat membeli dan menjual sekuritas setiap saat sesuai dengan kebutuhan. ${ }^{41}$

Demikian halnya dengan kegiatan pasar modal syariah yang merupakan salah satu aktivitas bisnis. Pasar modal syariah sebagai salah satu lembaga keuangan, mempunyai peran yang sangat strategis karena merupakan sumber dana jangka panjang. Keberadaan institusi ini bukan hanya sebagai wahana sumber pembiayaan yang dapat memenuhi kebutuhan dana, baik bagi swasta maupun pemerintah dan BUMN, tetapi juga sebagai sarana investasi yang melibatkan seluruh potensi dana masyarakat. Tidak terkecuali masyarakat muslim yang menginginkan suatu media investasi yang sesuai dengan syariah Islam.

Adapun tujuan pasar modal menurut pandangan Islam yaitu menciptakan pasar modal yang "beretika dan adil”. Seluruh transaksi di pasar modal harus dilaksanakan sesuai dengan norma etika Islam yang telah diatur dalam syariah. Pasar modal yang Islami adalah pasar modal yang ideal, yaitu yang memenuhi unsur "etik, fair/ transparan dan adanya unsur efisien". Obaidullah, mengutip pandangan Baruch Lev mengatakan, bahwa "pengertian etik dan fair adalah terdapatnya persamaan kesempatan (equality of opportunity), dimana seluruh pihak dalam pasar modal mendapatkan akses informasi yang sama dan relevan untuk mengevaluasi asset. ${ }^{42}$

Berdasarkan Fatwa DSN-MUI No. 40/DSN-MUI/X/2003 tentang Pasar Modal dan Pedoman Umum Penerapan Prinsip Syariah di Bidang Pasar Modal, prinsip syariah yang digunakan dalam Pasar Modal adalah: “Prinsip-prinsip yang didasarkan atas ajaran Islam yang penetapannya dilakukan oleh DSN-MUI, baik

\footnotetext{
${ }^{40}$ Ibid., hlm. 146.

${ }^{41}$ Ibid.

${ }^{42}$ Muhamad, Op. Cit., hlm. 149.
} 
ditetapkan dalam fatwa ini maupun dalam fatwa terkait lainnya". Adapun Konsep dasar hukum Islam pada Pasar Modal Syariah menurut fatwa tersebut antara lain adalah:43 1) Al-Qur'an, Firman Allah, antara lain: ...dan Allah menghalalkan jual beli dan mengharamkan riba... (QS.al-Baqarah:275) ${ }^{44}$; ...untuk tiap-tiap umat diantara kamu, Kami berikan aturan dan jalan yang terang... (QS. Al-Maidah:48); “Dan orangorang yang berjihad untuk (mencari keridhaan) Kami, benar-benar akan kami tunjukkan kepada mereka jalan-jalan Kami. Dan sesungguhnya Allah benar-benar beserta orang-orang yang berbuat baik." (QS.al-Ankabuut: 69); “Dan tidaklah Kami mengutus kamu melainkan untuk (menjadi) rahmat bagi alam semesta." (al-Anbiyaa: 107); Dan kami turunkan kepadamu al-kitab (Al-Qur'an) untuk menjelaskan sesuatu dan petunjuk serta rahmat dan kabar gembira bagi orang-orang yang berserah diri." (QS. An-Nahl: 89); 2) Hadis Nabi Muhammad SAW: “Janganlah kamu menjual sesuatu yang tidak ada padamu (HR.Al Khomsah dari Hukaim bin Hizam); “Rasulullah SAW melarang jual beli yang mengandung gharar" (HR. Muslim, Tirmidzi, Nasa'I, Abu Daud, dan Ibnu Majah dari Abu Hurairah); “Tidak halal (memberikan) pinjaman dan penjualan, tidak halal (menetapkan) 2 syarat dalam satu jual beli, tidak halal keuntungan sesuatu yang tidak ditanggung resikonya, dan tidak halal (melakukan) penjualan sesuatu yg tidak ada padamu" (HR. Al Khomsah dari Amr bin Syuaib dari ayahnya dari kakeknya.); “Kaum muslim (dalam kebebasan) sesuai dengan syarat dan kesepakatan mereka, kecuali syarat yang mengharamkan yang halal atau menghalalkan yang haram." (at-Tirmidzi); 3) Kaidah Fiqh: "Pada dasarnya, semua bentuk muamalah boleh dilakukan kecuali ada dalil yang mengharamkan."; 4) Pendapat Ulama : Ibnu Qudamah dalam Al-Mughni juz 5/173: Jika salah seorang dari dua orang berserikat membeli porsi mitra serikatnya, hukumnya boleh karena ia membeli milik pihak lain; Dr. Wahbah al-Zuhaili dalam Al-Fiqh Al-Islami wa Adillatuhu juz 3/1841: Bermuamalah dengan melakukan kegiatan transaksi atas saham hukumnya boleh, karena pemilik saham adalah mitra dalam perseroan sesuai dengan saham yang dimilikinya.

\footnotetext{
${ }^{43}$ Fatwa DSN-MUI No. 40/DSN-MUI/X/2003 tentang Pasar Modal Dan Pedoman Umum Penerapan Prinsip Syariah Di Bidang Pasar Modal

${ }^{44}$ Orang-orang yang makan (mengambil) riba tidak dapat berdiri melainkan seperti berdirinya orang yang kemasukan syaitan lantaran (tekanan) penyakit gila. Keadaan mereka yang demikian itu, adalah disebabkan mereka berkata (berpendapat), sesungguhnya jual beli itu sama dengan riba, padahal Allah telah menghalalkan jual beli dan mengharamkan riba. Orang-orang yang telah sampai kepadanya larangan dari Tuhannya, lalu terus berhenti (dari mengambil riba), maka baginya apa yang telah diambilnya dahulu (sebelum datang larangan); dan urusannya (terserah) kepada Allah. Orang yang kembali (mengambil riba), maka orang itu adalah penghuni-penghuni neraka; mereka kekal di dalamnya.
} 
Berdasarkan paparan di atas, pada dasarnya syariah membolehkan perdagangan sekuritas di pasar modal selama tidak melanggar kaidah fikih. Ada beberapa macam perdagangan yang dilarang menurut Fatwa Dewan Syariah Nasional No: 20/DSNMUI/IV/2001 Pasal 9 ayat (2) yaitu: a) najsy, atau penawaran palsu; b) bay'al-ma'dum, penjualan barang yang belum dimiliki (short selling); c) insider trading, penyebarluasan informasi yang menyesatkan atau memakai informasi orang untuk memperoleh keuntungan transaksi yang dilarang; d) melakukan investasi pada perusahaan yang pada saat transaksi (nisbah) utangnya lebih dominan daripada modalnya.

Lebih lanjut Pasal 10 fatwa tersebut menyebutkan kondisi emiten yang tidak layak, yaitu: a) apabila struktur utang terhadap modal sangat bergantung pada pembiayaan dari utang yang intinya merupakan pembiayaan ribawi; b) apabila suatu emiten nisbah utang terhadap modal lebih dari 82\% (utang 45\%, modal 55\%); c) apabila manajemen suatu emiten diketahui telah bertindak melanggar prinsip syariah. ${ }^{45}$

Mengacu pada aktivitas pasar modal syariah, gambaran mengenai pasar modal yang efisien, etik dan fair menurut Shefrin dan Statman (1993) yang dikutip oleh Obaidullah, mengandung tujuh karakteristik yaitu: ${ }^{46} 1$. bebas dari pemaksaan, investor memiliki hak untuk bertransaksi dan bebas membuat kontrak; 2 . bebas dari salah interpretasi, investor berhak mendapat informasi yang benar, sehingga tidak menimbulkan salah interpretasi; 3. hak untuk mendapat informasi yang sama, seluruh investor memiliki akses yang sama untuk mendapat satu set informasi yang khusus; 4 . hak untuk memproses informasi yang sama, sehingga tidak ada investor yang dirugikan; 5 . bebas dari gejolak hati, seluruh investor selayaknya terbebas dari berbuat kesalahan karena kurang pengendalian diri; 6 . hak bertransaksi pada harga yang efisien atau benar; 7 . hak untuk memiliki kekuatan tawar yang sama untuk bernegosiasi.

Mengacu pada uraian di atas, tampak bahwa informasi merupakan faktor yang mempunyai peran yang signifikan dalam melakukan transaksi di pasar modal syariah. Prinsip keterbukaan dan transparansi informasi penuh (full disclosure) diperlukan agar investor tidak dirugikan dan terhindar dari penyelewengan dan penipuan. Full disclosure dalam perdagangan merupakan unsur yang diharuskan dalam fikih tijarah. Para penjual wajib memberikan informasi yang lengkap berkaitan

\footnotetext{
${ }^{45}$ Muhamad Nafik HR, Op Cit., hlm. 200.

${ }^{46}$ Muhamad, Op Cit, hlm. 149-150.
} 
dengan barang dagangannya, baik kelebihan maupun kekurangannya. Mengenai hal ini, Rasullulah bersabda, “Tidaklah halal bagi seseorang menjual sesuatu, tanpa menerangkan kekurangan (cacat) pada barang itu." (HR Ahmad) ${ }^{47}$. Dengan diterapkannya prinsip full disclosure, maka aktivitas transaksi di pasar modal syariah dapat terhindar dari spekulasi.

Lain halnya dengan kegiatan transaksi di pasar modal konvensional, apabila ditelaah lebih dalam masih banyak aktivitasnya yang bertentangan atau melanggar prinsip syariah sebagaimana yang telah digariskan oleh fikih, diantaranya: 1. sekuritas yang diperdagangkan merupakan sekuritas emiten yang memproduksi barang dan jasa yang haram serta melanggar syariah; 2. menjual sekuritas yang belum dimiliki; 3. adanya manipulasi dan penipuan terutama berkaitan dengan transparansi atau keterbukaan informasi (full disclosure), dan emiten berisiko tinggi; 4. transaksi yang mengandung ketidakjelasan sekuritas yang diperdagangkan; 5. transaksi yang mengandung unsur riba; 6. rekayasa permintaan dan penawaran untuk permainan harga; 7 . transaksi perdagangan yang tidak memenuhi syarat dan rukun jual beli; 8. transaksi yang dibatasi oleh waktu dan atau dikaitkan dengan transaksi lainnya; 9. dua transaksi atau lebih dalam satu perjanjian jual beli. ${ }^{48}$

Aktivitas pasar modal tersebut di atas jelas melanggar prinsip syariah dan etika berbisnis. Menurut pandangan Islam, pemahaman etika dalam pasar modal syariah tidak diartikan secara sempit menyangkut "haqq" semata. Haqq menurut konsep Islam mempunyai aspek yang lebih luas, yaitu meliputi "hak dan kewajiban”. Keduanya bersumber dari hukum syariah yang diatur dalam Al-Qur'an dan As-Sunnah. Masalah etika dan efisiensi ditinjau dari aspek kemanfaatannya (masalih), merupakan dasar dari seluruh peraturan dalam sistem Islam. ${ }^{49}$ Sehubungan dengan hal tersebut, Fatwa DSN-MUI No.40/DSN-MUI/X/2003 menentukan kriteria jenis usaha perusahaan yang berkegiatan dalam pasar modal syariah tidak boleh bertentangan dengan prinsip syariah yaitu: 1 . memproduksi, mendistribusikan, memperdagangkan makanan yang non halal; 2 . memproduksi, mendistribusikan dan memperdagangkan minuman keras atau beralkohol; 3. menyelenggarakan perjudian dan yang tergolong judi seperti kasino, tebakan pertandingan olah raga, permainan ketangkasan; 4. menyelenggarakan jasa perbankan yang berbasis sistem bunga; 5 .

\footnotetext{
${ }^{47}$ Muhamad Nafik, Op Cit., hlm. 179

${ }^{48}$ Ibid., hlm. 200-201.

${ }^{49}$ Muhamad, Op Cit., hlm. 151.
} 
menyelenggarakan jasa asuransi yang memakai sistem bunga; 6. menyelenggrakan usaha hotel, restoran dan lain-lain yang menyediakan makanan, minuman non halal dan aktivitas yang bertentangan dengan prinsip-prinsip syariah.

Prinsip-prinsip syariah juga memberikan penekanan dalam pasar modal syariah yang berkenaan dengan: 1. kehalalan produk/jasa dari kegiatan usaha, karena menurut prinsip syariah, manusia hanya boleh memperoleh keuntungan atau penambahan harta dari hal-hal yang halal dan baik; 2. adanya kegiatan usaha yang spesifik dengan manfaat yang jelas, sehingga tidak ada keraguan akan hasil usaha yang akan menjadi objek dalam perhitungan yang diperoleh; 3. adanya mekanisme bagi hasil yang adil baik dalam untung maupun rugi menurut penyertaan masing-masing pihak; 4. penekanan pada mekanisme pasar yang wajar dan prinsip kehati-hatian baik pada emiten maupun investor.

Bapepam-LK (Lembaga Keuangan) sebagai badan pengawas pasar modal, telah melakukan langkah-langkah screening kepada masing-masing saham yang layak untuk masuk pada jenis syariah melalui beberapa tahapan berupa inti bisnis, image dan rasio keuangan. ${ }^{50}$

Adapun, yang merupakan instrumen Pasar Modal Syariah berdasarkan screening Bapepam-LK adalah: "Efek sebagaimana dimaksud dalam peraturan perundangundangan di bidang pasar modal, yang akad, pengelolaan perusahaan, maupun cara penerbitannya memenuhi prinsip-prinsip syariah". Menurut Obaidullah, instrumen penting yang dapat diperdagangkan sebagai hasil pemikiran hukum Islam diantaranya: 1) Dana Mudharabah (Mudharabah Fund), merupakan instrumen keuangan bagi investor untuk pembiayaan bersama proyek besar berdasarkan prinsip bagi hasil; 2) Saham Biasa Perusahaan (Common Stock), adalah saham yang diterbitkan oleh perusahaan yang didirikan untuk kegiatan bisnis yang sesuai dengan Islam; 3) Obligasi Mudharabah, obligasi ini diterbitkan untuk pembiayaan proyek yang menghasilkan uang atau proyek yang terpisah dari kegiatan umum perusahaan; 4) Obligasi Bagi Hasil, obligasi yang diterbitkan oleh perusahaan yang aktivitas bisnisya, sesuai dengan syariah Islam dan berdasarkan prinsip bagi hasil; 5) Saham Preferen (Prefered Stock), saham ini memiliki hak-hak istimewa seperti deviden tetap dan prioritas dalam likuidasi. Karena ada unsur pendapatan tetap (seperti bunga) maka dilarang menurut hukum Islam. Namun ini masih menjadi bahan perdebatan..$^{51}$

\footnotetext{
${ }^{50}$ Agus.Y, 242 saham dinyatakan sesuai syariah, www.pkes.org, ,diakses tgl.12 Agustus 2012

${ }^{51}$ Muhamad, Op. Cit, hlm. 152
} 
Dari uraian yang telah dipaparkan, maka akan terlihat perbedaan yang sangat mendasar antara pasar modal konvensional dengan pasar modal syariah. Perbedaan fundamental antara pasar modal konvensional dengan pasar modal syariah adalah: 1. pasar modal syariah tidak mengenal kegiatan perdagangan semacam short selling, beli atau jual dalam waktu yang amat singkat untuk mendapatkan keuntungan antara selisih jual dan beli; 2. pemegang saham syariah adalah pemegang saham untuk jangka relatif panjang. Hal tersebut membawa dampak positif, perusahaan tentu akan mendapatkan pemegang saham yang jelas lebih menaruh perhatian dan rasa memiliki. Hal ini akan menjadi kontrol yang efektif; 3. perusahaan dan pemegang saham merupakan mitra yang saling menghargai dan mengikatkan, sehingga komunikasi kedua belah pihak akan bertemu pada upaya mencapai kebaikan bagi kedua belah pihak; 4. karakteristik pemilihan saham syariah yang hanya mengutamakan keuntungan yang akan dibagi atau kerugian yang akan ditanggung bersama (profit-loss sharing) tidak akan menciptakan fluktuasi kegiatan perdagangan yang tajam dan bersifat spekulatif.

\section{Penutup}

Berdasarkan uraian di atas, dapat diperoleh kesimpulan, sebagai berikut: pertama, konsep investasi menurut hukum Islam adalah semua bentuk investasi dilakukan dalam rangka ibadah kepada Allah untuk mencapai kebahagiaan lahir batin di dunia dan akhirat baik bagi generasi sekarang maupun generasi yang akan datang, jadi buka semata-mata urusan duniawi belaka. Kedua, investasi menurut hukum Islam sangat berbeda dengan pemahaman investasi secara konvensional. Unsur kemaslahatan dunia dan akhirat mempunyai prioritas yang utama, sehingga investasi bertujuan jangka panjang. Sementara spekulasi bertujuan hanya untuk mencari untung dalam jangka pendek tanpa memperhatikan kepentingan orang lain serta sering kali menggunakan cara-cara yang melanggar rule of the game yang berlaku. Selain itu walaupun investasi syariah tidak akan luput dari adanya risiko, namun investor merasakan kenyamanan dalam berinvestasi karena tidak adanya unsur riba, maysir (judi), gharar (ketidakpastian). Investasi dilakukan dengan tuntunan fikih, bukan karena keinginan hawa nafsu sebagaimana dilakukan oleh spekulator yang dapat merugikan banyak pihak. Ketiga, hukum Islam mempunyai perspektif yang mendukung terhadap pasar modal syariah. Dukungan hukum Islam terhadap 
aktivitas investasi di pasar modal syariah terlihat dari konsep dasar hukum Islam dalam Al-Qur'an, hadis, fikih dan pendapat para ulama yang mendukung kegiatan pasar modal syariah.

Sudah saatnya setiap muslim yang terlibat dalam sektor ini menunjukkan bahwa Islam adalah sebagai jalan hidup yang dapat diamalkan secara komprehensif dan istiqamah. Oleh sebab itu, dalam aktivitas pasar modal syariah perlu untuk lebih dioptimalkan lagi eksistensi hukum Islam, karena belum tergali sepenuhnya nilainilai syariah dalam berinvestasi syariah. Mengingat pasar modal syariah mempunyai kedudukan dan peran yang sangat strategis dalam kegiatan ekonomi nasional dan aktivitas ini mempunyai manfaat yang holistik baik bagi emiten, investor, maupun pemerintah, maka mendesak dibentuknya undang-undang pasar modal syariah. Hal ini akan lebih mempertegas berlakunya hukum Islam secara kaffah demi kemaslahatan dalam bidang investasi di pasar modal.

\section{Daftar Pustaka}

Gede Ary Suta,I Putu, Menuju Pasar Modal Modern, SAD Satria Bhakti, Jakarta, 2000. Hamidi, M.Luthfi, Jejak-jejak Ekonomi Syariah, Senayan Abadi Publishing, Jakarta, 2003. Hanitijo Soemitro, Ronny, Metodologi Penelitian Hukum dan Yurimetri, Ghalia Indonesia, Jakarta, 1990.

Huda, Nurul, Mustafa Edwin Nasution, Investasi pada Pasar Modal Syariah, Kencana Prenada Media Group, Jakarta, 2007.

Manan, Abdul, Aspek Hukum dalam Penyelenggaraan Investasi di Pasar Modal Syariah Indonesia, Kencana Prenada Media Grup, Jakarta, 2009.

Muhamad, Dasar-dasar Keuangan Islam, Ekonosia, Fakultas Ekonomi UII, Yogyakarta, 2004.

Nafik HR, Muhamad, Bursa Efek dan Investasi Syariah, Serambi Ilmu Semesta, Jakarta 2009.

Syafii Antonio, Muhammad, Bank Syariah dalam Teori dan Praktek, Gema Insani, Jakarta, 2001.

Suhardo, Etty S., Menuju Hukum Investasi yang Kondusif, dalam Jurnal Law Review, Vol IX, No.2-Nopember 2009, Fakultas Hukum Universitas Pelita Harapan

Soerjono Soekanto, Penelitian Hukum Normatif: Suatu Tinjauan Singkat, Jakarta, Raja Grafindo Persada, 1995.

Fatwa DSN-MUI No. 40/ DSN-MUI/X/2003 tentang Pasar Modal dan Pedoman 
Umum Penerapan Prinsip Syariah di Bidang Pasar Modal.

Fatwa DSN-MUI No. 20/ DSN -MUI/IV/2001 tentang Pedoman Investasi untuk Reksa dana Syariah.

Undang-Undang No. 8 Tahun 1995 tentang Pasar Modal

Agus.Y www.pkes.org, google, 242 Saham Dinyatakan Sesuai Syariah. 